\title{
Penerapan Logika Matematika Terhadap Permasalahan Sosial Uang Panai’ di Masyarakat Bugis-Makassar
}

\author{
Syafruddin Side ${ }^{1}$, Hisyam Ihsan ${ }^{1}$, dan Abdul Kadir ${ }^{1, \text { a) }}$ \\ ${ }^{1}$ Jurusan Matematika FMIPA Universitas Negeri Makassar, 90224 \\ a)kadsyah777@gmail.com
}

\begin{abstract}
Abstrak. Jenis penelitian ini merupakan penelitian murni (kajian teori dan aplikasi dari logika matematika) yang bertujuan untuk mengetahui lebih lanjut mengenai permasalahan sosial Uang Panai' di daerah Sulawesi Selatan. Penelitian ini dilakukan dengan mengumpulkan data dari responden, lalu menyaJikannya kedalam bentuk premis yang kemudian dituangkan kedalam logika matematika untuk menentukan nilai kebenaran dan menyimpulkannya. Dari panelitian ini diperoleh beberapa hal mengenai permasalahan Sosial Uang Panai' diantaranya yaitu hal-hal yang menyebabkan mahalnya Uang Panai' dan dampak-dampak dari mahalnya Uang Panai', baik itu dampak positif maupun dampak negatifnya.

Kata kunci: Uang Panai', logika matematik
\end{abstract}

\begin{abstract}
This research is categorized as pure research (a study of theory and implementation from math logic) which is aimed to know more about social problem of Uang Panai' in south sulawesi. This research conducted by collection data from respondent and then presented in the statements form wich would be presented in math logic to determine the true value and conclude it. The result of this research showed some social cases of Uang Panai' included the factors which caused the high cost of Uang Panai' and the effects of it (positive and negative effect).
\end{abstract}

Keywords: Uang Panai', math logic

\section{PENDAHULUAN}

Matematika merupakan salah satu ilmu yang memiliki peranan penting terhadap kemajuan peradaban manusia. Berbagai manfaat dapat diperoleh dengan mempelajari matematika antara lain, seseorang memiliki dan terbiasa berpikir sistematis, ilmiah, dan logis. Selain itu manfaat mempelajari matematika adalah dapat digunakan sebagai pembimbing pola pikir, terutama dalam pengambilan keputusan. Salah satu cabang ilmu matematika yang mempelajari tentang prinsip pengambilan keputusan adalah logika matematika. Logika matematika memberikan landasan tentang bagaimana cara mengambil kesimpulan.

Peneliti yang telah menerapkan logika matematika dalam penelitiannya, yaitu Mohammad Aulia Syifa (2011) yang berjudul "Penerapan logika matematika dalam hukum waris menurut perdata barat". Namun, penelitian tersebut hanya menggunakan logika dalam bidang hukum, sehingga penulis ingin menerapkan logika matematika dalam bidang sosial.

Ketika berbicara mengenai bidang sosial, maka pasti muncul topik mengenai suatu permasalahan sosial, baik itu di suatu keluarga, daerah masyarakat, suku dan lain sebagainya. Sama seperti halnya di daerah Sulawesi Selatan, tepatnya di daerah yang penduduknya 
mayoritas suku Bugis-Makassar. Dimana di daerah ini terdapat permasalahan sosial yang sangat menyita perhatian publik, masalah yang menjadi momok menakutkan bagi para pria untuk mendekati wanita Bugis-Makassar, yaitu masalah mahalnya Uang Panai' wanita di suku BugisMakassar.

\section{Logika Matematika}

Pernyataan Majemuk

1. Konjungsi

2. Disjungsi

TABEL 1. Kebenaran Logika Konjungsi

\begin{tabular}{lll}
$\mathbf{P}$ & $\mathbf{q}$ & $\mathbf{p} \wedge \mathbf{q}$ \\
\hline B & B & B \\
B & S & S \\
S & B & S \\
S & S & S \\
\hline
\end{tabular}

TABEL 2. Kebenaran Logika disjungsi

\begin{tabular}{lll}
\hline $\mathbf{P}$ & $\mathbf{q}$ & $\mathbf{p} \vee \mathbf{q}$ \\
\hline $\mathrm{B}$ & $\mathrm{B}$ & $\mathrm{B}$ \\
$\mathrm{B}$ & $\mathrm{S}$ & $\mathrm{B}$ \\
$\mathrm{S}$ & $\mathrm{B}$ & $\mathrm{B}$ \\
$\mathrm{S}$ & $\mathrm{S}$ & $\mathrm{S}$ \\
\hline
\end{tabular}

3. Implikasi

TABEL 3. Kebenaran Logika implikasi

\begin{tabular}{ccc}
\hline $\mathbf{P}$ & $\mathbf{q}$ & $\mathbf{p ~} \Rightarrow \mathbf{q}$ \\
\hline B & B & B \\
B & S & S \\
S & B & B \\
S & S & B \\
\hline
\end{tabular}

4. Biimplikasi

TABEL 4. Kebenaran Logika biimplikasi

\begin{tabular}{lll}
\hline P & $\mathbf{q}$ & $\mathbf{p} \Leftrightarrow \mathbf{q}$ \\
\hline B & B & B \\
B & S & S \\
S & B & S \\
S & S & B \\
\hline
\end{tabular}

\section{Penarikan Kesimpulan}

Kesimpulan dapat dilakukan dengan menelaah premis atau pernyataan-pernyataan yang kebenarannya telah dketahui. Beberapa konsep penarikan kesimpulan di dalam logika matematika berikut ini:

1. Modus Ponens

Premis 1: $p \Rightarrow q$

Premis $2: \mathrm{p}$

Kesimpulan : q 
2. Modus Tollens

Premis $1: p \Rightarrow q$

Premis $2: \sim \mathrm{q}$

Kesimpulan : p p

3. Silogisme

Premis $1: p \Longrightarrow q$

Premis 2: $q \Rightarrow r$

Kesimpulan $: p \Longrightarrow r$

\section{Uang Panai'}

Uang Panai'/doe' balanja adalah "uang antaran" yang harus diserahkan oleh pihak keluarga calon mempelai laki-laki kepada pihak keluarga calon mempelai perempuan (Syarifuddin, Ayu \& Ratna; 2015). Uang Panai' tidak terhitung sebagai mahar pernikahan, melainkan sebagai uang adat. Namun terbilang wajib, sehingga oleh masyarakat, Uang Panai'mendapatkan perhatian lebih besar dibandingkan dengan mahar, dan dianggap sebagai sesuatu hal yang sangat menentukan kelancaran jalannya proses perkawinan.

\section{METODE PENELITIAN}

Metode yang digunakan dalam penelitian ini adalah metode mengumpulkan data dari responden, yaitu memberikan quisioner/angket kepada responden diberbagai kabupaten/kota di Sulawesi Selatan untuk diisi sesuai dengan pendapat mereka. Lalu data dari responden tersebut disaJikan kedalam bentuk premis/penyataan, kemudian premis tersebut dituangkan kedalam logika matematika implikasi untuk menentukan nilai kebenarannya, berdasarkan pendapat terbanyak dari responden. Setelah itu premis yang telah diketahui kebenarannya kemudian disimpulkan dengan konsep penarikan kesimpulan didalam logika matematika.

\section{HASIL DAN PEMBAHASAN}

\section{Premis-premis Tentang Mahalnya Uang Panai'}

Penentuan nilai benar/salah dari premis dibawah ini berdasar pada pendapat terbanyak dari responden.

1. Uang Panai' mahal. (benar).

2. Pendidikan mempengaruhi mahalnya Uang Panai'. (benar).

3. Keturunan/kasta mempengaruhi mahalnya Uang Panai'. (benar).

4. Tingkat ekonomi mempengaruhi mahalnya Uang Panai'. (benar).

5. Jumlah bersaudara mempengaruhi mahalnya Uang Panai'. (salah).

6. Kondisi fisik mempengaruhi mahalnya Uang Panai'. (benar).

7. Status gadis mempengaruhi mahalnya Uang Panai'. (benar).

8. Gelar hajjah mempengaruhi mahalnya Uang Panai'. (benar).

9. Pesta meriah adalah dampak positif dari mahalnya Uang Panai'. (benar).

10. Lama baru menikah merupakan dampak negatif dari mahalnya Uang Panai'. (benar).

11. Maraknya kawin lari/nikah siri' merupakan dampak negatif dari mahalnya Uang Panai'. (benar).

12. Strata dalam masyarakat meningkat merupakan dampak positif dari mahalnya Uang Panai'. (benar). 
13. Nilai popularitas meningkat merupakan dampak positif dari mahalnya Uang Panai'. (benar).

14. Tidak menikah merupakan dampak negatif dari mahalnya Uang Panai’. (benar).

\section{Premis-premis yang Telah Diketahui Kebenarannya dengan Konsep Logika Matematika Implikasi}

1. JikaUang Panai' mahal maka pendidikan mempengaruhi mahalnya Uang Panai'.

2. JikaUang Panai' tidak mahal maka pendidikan mempengaruhi mahalnya Uang Panai'.

3. JikaUang Panai' tidak mahal maka pendidikan tidak mempengaruhi mahalnya Uang Panai'.

4. JikaUang Panai' mahal maka keturunan/kasta mempengaruhi mahalnya Uang Panai'.

5. JikaUang Panai' tidak mahal maka keturunan/kasta mempengaruhi mahalnya Uang Panai'.

6. JikaUang Panai' tidak mahal maka keturunan/kasta tidak mempengaruhi mahalnya Uang Panai'.

7. JikaUang Panai' mahal maka tingkat ekonomi mempengaruhi mahalnya Uang Panai'.

8. JikaUang Panai' tidak mahal maka tingkat ekonomi mempengaruhi mahalnya Uang Panai'.

9. JikaUang Panai' tidak mahal maka tingkat ekonomi tidak mempengaruhi mahalnya Uang Panai'.

10. JikaUang Panai' mahal maka jumlah bersaudara tidak mempengaruhi mahalnya Uang Panai'.

11. JikaUang Panai' tidak mahal maka jumlah bersaudara mempengaruhi mahalnya Uang Panai'.

12. JikaUang Panai' tidak mahal maka jumlah bersaudara tidak mempengaruhi mahalnya Uang Panai'.

13. JikaUang Panai' mahal maka kondisi fisik mempengaruhi mahalnya Uang Panai'.

14. JikaUang Panai' tidak mahal maka kondisi fisik mempengaruhi mahalnya Uang Panai'.

15. JikaUang Panai' tidak mahal maka kondisi fisik tidak mempengaruhi mahalnya Uang Panai.

16. JikaUang Panai' mahal maka status gadis mempengaruhi mahalnya Uang Panai'.

17. JikaUang Panai' tidak mahal maka status gadis mempengaruhi mahalnya Uang Panai'.

18. JikaUang Panai' tidak mahal maka status gadis tidak mempengaruhi mahalnya Uang Panai'.

19. JikaUang Panai' mahal maka gelar hajja mempengaruhi mahalnya Uang Panai'.

20. JikaUang Panai' tidak mahal maka gelar hajja mempengaruhi mahalnya Uang Panai'.

21. JikaUang Panai' tidak mahal maka gelar hajja tidak mempengaruhi mahalnya Uang Panai'.

22. JikaUang Panai' mahal maka pesta meriah merupakan dampak positif dari mahalnya Uang Panai'.

23. JikaUang Panai' tidak mahal maka pesta meriah merupakan dampak positif dari mahalnya Uang Panai'.

24. JikaUang Panai' tidak mahal maka pesta meriah bukan merupakan dampak positif dari mahalnya Uang Panai'.

25. JikaUang Panai' mahal maka strata dalam masyarakat meningkat merupakan dampak positif dari mahalnya Uang Panai'.

26. JikaUang Panai' tidak mahal maka strata dalam masyarakat meningkat merupakan dampak positif dari mahalnya Uang Panai'.

27. JikaUang Panai' tidak mahal maka strata dalam masyarakat meningkat bukan merupakan dampak positif dari mahalnya Uang Panai'. 
28. JikaUang Panai' mahal maka nilai popularitas meningkat merupakan dampak positif dari mahalnya Uang Panai'.

29. JikaUang Panai' tidak mahal maka nilai popularitas meningkat merupakan dampak positif dari mahalnya Uang Panai'.

30. JikaUang Panai' tidak mahal maka nilai popularitas meningkat bukan merupakan dampak positif dari mahalnya Uang Panai'.

31. JikaUang Panai' mahal maka lama baru menikah merupakan dampak negatif dari mahalnya Uang Panai'.

32. JikaUang Panai' tidak mahal maka lama baru menikah merupakan dampak negatif dari mahalnya Uang Panai'.

33. JikaUang Panai' tidak mahal maka lama baru menikah bukan merupakan dampak negatif dari mahalnya Uang Panai'.

34. JikaUang Panai' mahal maka maraknya kawin lari/nikah siri' merupakan dampak negatif dari mahalnya Uang Panai'.

35. JikaUang Panai' tidak mahal maka maraknya kawin lari/nikah siri' merupakan dampak negatif dari mahalnya Uang Panai'.

36. JikaUang Panai' tidak mahal maka maraknya kawin lari/nikah siri' bukan merupakan dampak negatif dari mahalnya Uang Panai'.

37. JikaUang Panai' mahal maka tidak menikah merupakan dampak negatif dari mahalnya Uang Panai'.

38. JikaUang Panai' tidak mahal maka tidak menikah merupakan dampak negatif dari mahalnya Uang Panai'.

39. JikaUang Panai' tidak mahal maka tidak menikah bukan merupakan dampak negatif dari mahalnya Uang Panai'.

\section{Premis-premis Kesimpulan}

Premis-premis kesimpulan berikut diperoleh dari menyimpulkan premis-premis yang sebelumnya telah diketahui kebenarannya dalam logika implikasi, dengan konsep penarikan kesimpulan dalam logika matemtika.

1. Uang Panai ' mahal dan pendidikan mempengaruhi mahalnya uang panai'.

2. Uang Panai' mahal dan keturunan/kasta mempengaruhi mahalnya uang panai'.

3. Uang Panai' mahal dan tingkat ekonomi mempengaruhi mahalnya uang panai'.

4. Uang Panai' mahal dan jumlah bersaudara tidak mempengaruhi mahalnya uang panai'.

5. Uang Panai' mahal dan kondisi fisik mempengaruhi mahalnya uang panai'.

6. Uang Panai' mahal dan status gadis mempengaruhi mahalnya uang panai'.

7. Uang Panai' mahal dan gelar hajjah mempengaruhi mahalnya uang panai'.

8. Uang Panai' mahal dan pesta meriah merupakan dampak positif dari mahalnya Uang Panai'.

9. Uang Panai' mahal dan strata dalam masyarakat meningkat merupakan dampak positif dari mahalnya Uang Panai'.

10. Uang Panai' mahal dan nilai popularitas meningkat merupakan dampak positif dari mahalnya Uang Panai'.

11. Uang Panai' mahal dan lama baru menikah merupakan dampak negatif dari mahalnya Uang Panai'.

12. Uang Panai' mahal dan maraknya kawin lari/nikah siri' merupakan dampak negatif dari mahalnya Uang Panai'.

13. Uang Panai' mahal dan tidak menikah merupakan dampak negatif dari mahalnya Uang Panai'. 


\section{Pembahasan}

Pada penelitian Rika Elvira (2014), hasil yang diperoleh mengetahui bagaimana kedudukan Uang Panai' dalam aspek perjanjian, serta mengetahui seperti apa penerapan sanksi apabila pihak laki-laki melakukan ingkar janji dari kesepakatan Uang Panai' dalam perkawinan suku Bugis Makassar.

Sementara untuk penelitian ini dijelaskan mengenai bagaimana cara menuangkan permasalahan sosial masyarakat Bugis-Makassar yaitu mahalnya Uang Panai', kedalam konsep logika matematika. Mulai dari membuat premis tentang mahalya Uang Panai', sampai memperoleh premis-premis kesimpulan tentang mahalnya Uang Panai'. Sehingga diperolehlah hal-hal yang berkaitan dengan permasalahan mahalnya sosial Uang Panai' dimasyarakat Bugis-Makassar, seperti penyebab mahalnya Uang Panai', serta dampak-dampak dari mahalnya Uang Panai', baik itu dampak positif maupun dampak negatif.

\section{KESIMPULAN}

\section{Hal-hal yang mempengaruhi mahalnya Uang Panai’ yaitu:}

1. Pendidikan

2. Keturunan/kasta

3. Tingkat ekonomi

4. Kondisi fisik

5. Status gadis

6. Gelar hajja

\section{Dampak positif dari mahalnya Uang Panai’ yaitu:}

1. Pesta meriah

2. Strata dalam masyarakat meningkat

3. Nilai popularitas meningkat

\section{Dampak negatif dari mahalnya Uang Panai’ yaitu:}

1. Lama baru menikah

2. Maraknya kawin lari/nikah siri'

3. Tidak menikah

\section{DAFTAR PUSTAKA}

Marwanto, Murniati, Warsini. (2008). Mathematics For Senior Hight Scool Year X. Jakarta : Yudistira.

Monginsidi, Reski. (2016). Uang Panai (Dui Menre Naseng Ogie).http://silbus.blogspot.co.id/2016/02/tingginya-uang-penai-suku-bugis.html. Pada tanggal 06 Oktober 2016 diakses pada pukul 20.30 WITA.

Rahayu, Sri., Yudi. (2015). Uang Nai': Antara Cinta Dan Gengsi.Jurnal Akuntansi Multiparadigma, 6(2).175-340.

Rachmat, Setiadi. (2004). Pengantar Logika Matematika. Bandung : Informatika.

Satriana, Eka. (2015). Makna Ungkapan Pada Upacara Perkawinan Adat Bulukumba di Desa Buhung Bundang Kec. Bontotiro Kab. Bulukumba. Jurnal Humanika, 3(15). 
Sulistiyono., Kuntarti., Kurnianingsih, Sri. (2010). Mathematics For Senior Hight Scool grade $X$ semester 2. Jakarta: Esis

Sulta, Ibnu. (2016). "Uang Panai" Antara Gengsi dan Tradisi. http://www.soppengterkini.com/2016/07/panai-antara-gengsi-dan-tradisi.html. diakses pada tanggal 06 Oktober 2016.

Soesianto, F., Dwijono, Djoni. (2003). Logika Proposisional. Yogyakarta : Andi.

Syarifuddin., Ayu, Ratna. (2015). Story of Bride Price: Sebuah Kritik Atas Fenomena Uang Panaik Suku Makassar. Jurnal Akuntansi Multiparadigma, 6(1). 1-174.

Upu, Hamzah. (2013). English For Basic Mathematics. Makassar: Pustaka Refleksi. 